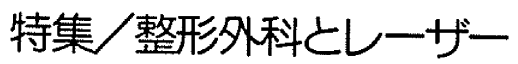

\author{
レーザーの腰椎手術への応用 \\ 里見 和彦, 河合 大, 小川潤 \\ 杏林大学医学部整形外科 \\ T181-8611 東京都三鹰市新川 $6-20-2$ \\ TEL $\quad 0422-47-5511$ FAX $0422-48-4206$
}

\title{
Laser disc surgery for lumbar disc disorders
}

Kazuhiko SATOMI, Dai KAWAI, and Jun OGAWA Department of Orthopaedic Surgery, Kyorin University School of Medicine 6-20-2, Shinkawa, Mitaka-shi, 181-8611 JAPAN

\section{要 旨}

Nd-YAGレーザーを用いて椎間板減圧術を施行した腰椎椎間板へルニア56例につき，その 手術成績, 術後の画像变化につき検討した。臨床症状の術後平均改善率は56\%, Henderson の基準では優，良合わせた有効率は61\%であった，成績に不満足で観血的手術が 6 例に行われ た。術後, 単純X線像上明らかな椎間狭小化はみられなかった，MRI上，椎間板あるいは軟 骨終板の信号変化が14例にみられたが，それによる症状悪化例はなかった。レーザー椎間板減 圧術は，椎間板へルニアに対する安全かつ有効な治療法の一つである.

キーワード: Nd-YAGレーザー, 椎間板ヘルニア, 腰椎, 軟骨終板, 副作用

\begin{abstract}
Percutaneous Nd-YAG laser disc decompression was performed in 56 patients with lumbar disc herniation. Recovery rate of clinical symptoms was $56 \%$ in an average according to JOA scores, and effective results was observed in $61 \%$ of patients by Henderson's evaluation of functional capacity postoperatively. No significant decrease of disc height was observed on postoperative radiographs of lumbar spine. Changes of signal intensity either disc or cartilaginous end plate were observed in 14 patients on MRI, however no deterioration of clinical symptoms occurred by this changes. Present results showed that laser disc decompression for lumbar disc herniation was an effective and safe method of the treatment.
\end{abstract}


Key words: Nd-YAG laser, disc herniation, lumbar spine, cartilaginous end plate, complication

\section{はじめに}

レーザー照射による腰椎椎間板ヘルニアの治療 は，米国のCh O y 報告以来多数の報告が見ら れる1・2，我が国では米澤らによる長期にわたる 基礎的研究の後, 1992年から臨床応用がなされて きだ.。我々は, 1994 年以来Nd-YAGレー ザーを用いて経皮的レーザー椎間板減圧術（以下 PLDD）を行ってきだ・6. . 本法は, 現在保 険適応がなく，また最近は副作用の報告がみられ るようになりッ."，まだ多くの課題を抱えている 治療法である，本稿では自験例の治療成績上椎間 板や椎体への悪影響につき報告し，本法の適応と 問題点を明らかにしたい.

\section{レーザー発生装置}

PLDDに使用されるレーザーは，蒸散能力に 優れるYAGレーザーが使用される，Choyらや 米澤らはNd (neodymium) -YAG (yttrium alminium garnet）をもちいているが，最近は 鏡視下に照射でき，副作用も少ないと思われる Ho（holminus）-YAGレーザーを使用する報 告が多くなっている(1)。我々は, 長田電機工業

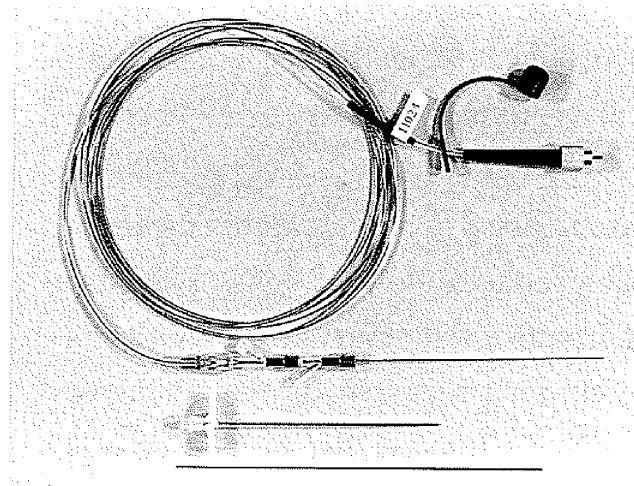

図 1 レーザー照射キット（長田電機工業社製） 上より石英ファイバーの通っているレーザ一針。 外筒，椎間板赖入ガイド針を示す.
社製の波長 $1064 \mathrm{~nm}$ ，連続発振型のNd-YAG レーザー（導光路はコア径200あるいは400 英ファイバーを使用)を用いてきたのでその方法 を紹介するら゙。レーザー照射キットを図１に示す。

\section{手技の実際}

患者を健側下の側臥位とし，X線透視下で皮虞 に局所麻酔を行った後ガイド針を椎間板正中に刺 入する，刺入法は，椎間板造影手技に準じ後側方 から刺入する":。腰の下に枕を入れて椎間板側 方が十分に開くようにするが，L 5/S間では刺 入できない例があり，本法の限界である。つぎに ガイド針を利用して外筒を椎間板に刺入する，さ らにガイド針を拔き，代わりに外筒内にレーザー ファイバーを刺入し，レーザー照射を開始する

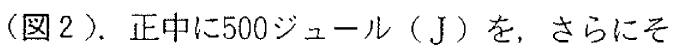
の前後 5 mmの部位に500 J ずつ照射する，部位を 移動させる前に椎間板内圧を測定し12)，椎間板 内圧の減少が一定になったことを確認する（図 3）。また，針䔟動後はX線透視により針先の位 置を確認する.

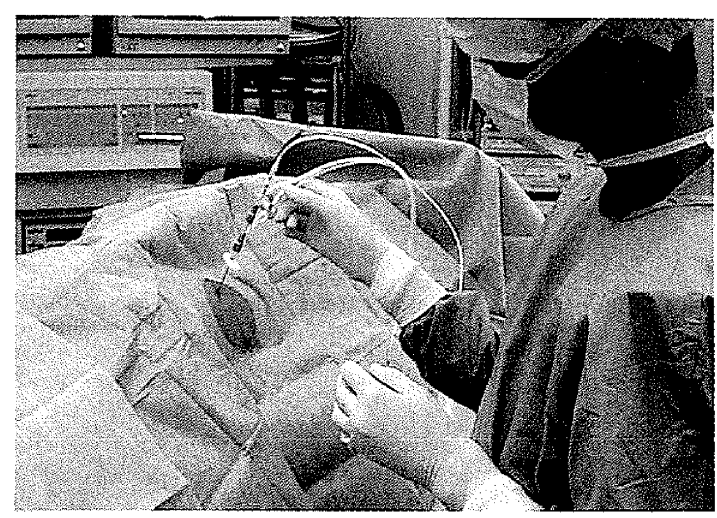

図 2 レーザー照射野

患者は側臥位となり，術者はガウンテクニックで 照射老行う。術者は吸引管を把持している。 


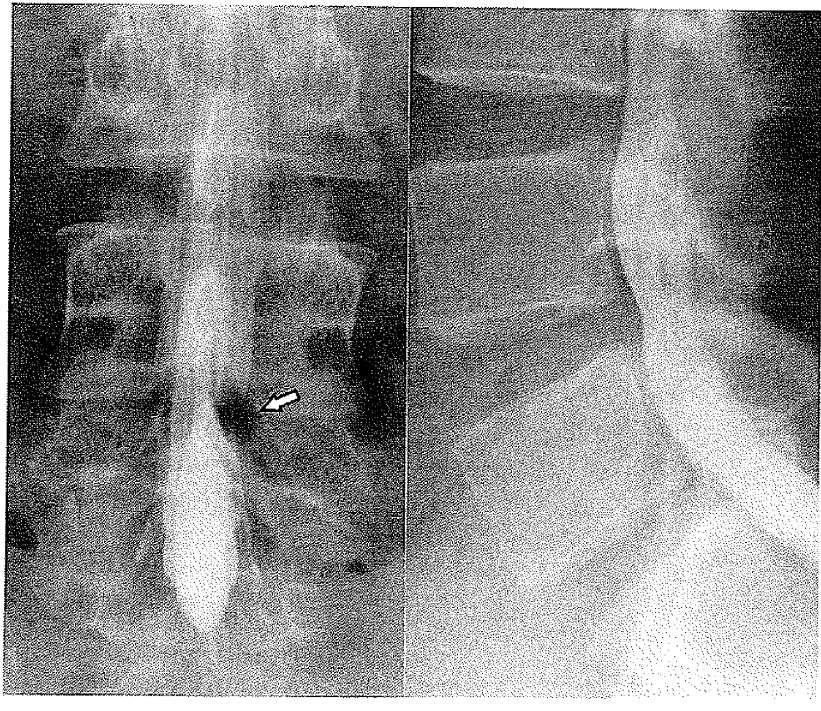

(a)

(b)

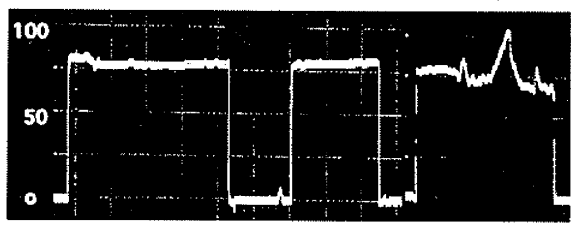

(c)

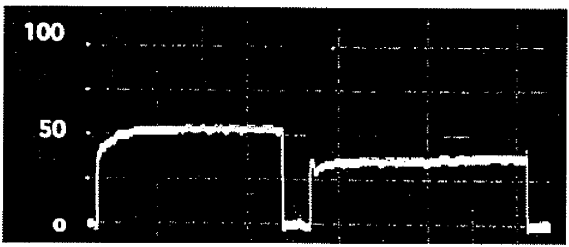

(d)

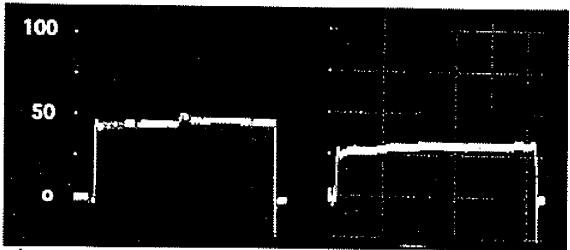

(e)

図 3 椎間板内圧測定例（33歳，男性）

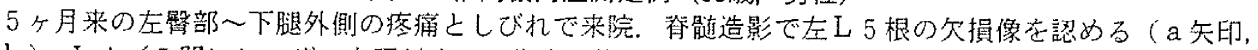
b). L 4 / 5 間にレーザ一を照射する. 術中, 椎間板の体軸に対しての水平圧 (図c, d, e左)上琹 直圧（中あるいは右）を測定する.1080 J照射後，照射前の内圧(c)に比しはぼ半滅したが(d)，以後1620 J照射まで生の低下は確認できず(e)，ここまでとする。術後，下肢症状は軽快した。腹圧をかけた時の 椎間板内生 ( $\mathrm{c}$ 右端) の上昇の变化も内圧隇少の判断に利用できる。

protrusion
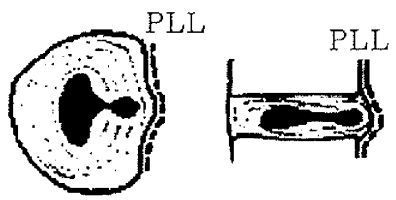

subligamentous extrusion
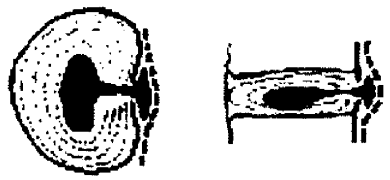

tarnsligamentous extrusion
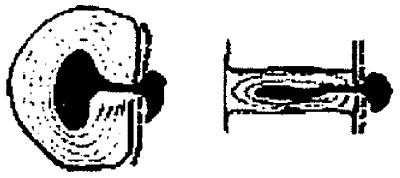

sequestration
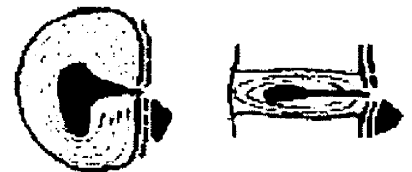

図 4 ヘルニアのタイプ

髄核が線維輪内に脱出するものはprotrusion, 線維輪を穿破したものをextrusion, 脱出遊離 したものをsequestrationと呼称する.さらに extrusionのう方娞緃勒带(PLL)を穿破したも のをtransligamentous extrusionと分ける。
症 例

1994年から現在まで当院で施行したPLDD症 例は68例である，術後 6 か月以上経過した症例は 56例（男性39例，女性17例) で，その手術時年齢 は平均29歳 $(9-52$ 歳) であった。ヘルニア高位 はL $3 / 4$ が 1 例，L $4 / 5$ が42例，L $5 / \mathrm{S}$ が 12例， L 3 $/ 4 ， 4 / 5$ が1例で，ヘルニアの夕 イプ (図 4) 13) はprotrusion 11例, subligamentous extrusion (以下SLE) 41例, transligamentous extrusion (以下TLE) が 4 例で あった。手技は 9 歳の 1 例を除き局所麻酔下で側 臥位で行った。レーザー照射量は平均1817（1305 -2420）Jであった，治療成績は，日整会腰痛治 療成績判定基準（以下JOAスコア，表 1) と改 善率1'ならびにHendersonの基準により日常生 活動作を優，良，可，不可の 4 段階で評価した

（表 2）・，手術に移行した例についてはその 要因を調查した。

術後の画像变化は，術前後の画像のそろった 30 


\section{表 1 腰痛疾患治療成績判定基準}

I. 自覚症状

A. 腰痛に関して
a，まったく腰痛はない
b、時に軽い腰痛がある
c．常に腰痛があるか、あるいは
時にかなりの腰痛がある
d. 常に激しい腰痛がある

B．下肢痛およびシビレに関して
a. まったく下肢痛, シビレがない
b. 時に軽い下肢痛，シビレがある
c. 常に下肢痛, シビレがあるか，あるい は時にかなりの下肢痛, シビレがある
d. 常に激しい下肢誦, シビレがある

C. 歩行能力について
a. まったく正常に歩行が可能
b. $500 \mathrm{~m}$ 以上歩行可能であるが疼痛, シビレ，脱力を生じる
c. $500 \mathrm{~m}$ 以下の歩行で疼痛, シビレ, 脱力を生じ，歩けない
d. $100 \mathrm{~m}$ 以下の歩行で疼痛. シビレ, 脱力を生じ，歩けない

III. 日常生活動作
a、寝がえり動作
b. 立ち上がり動作
c. 洗顔動作
d，中腰姿勢または立位の持続
e，長時間坐位（1時間位）
f、重量物の挙上または保持
g. 歩行

非常に困難
0
0
0
0
0
0
0

IV. 耪胱機能
a. 正常
b. 軽度の排尿困難（頻尿，排尿遅延，残尿感）
c . 高度の排尿困難（失禁，尿閉）
注：㲾路湥患による排尿障害を除外する

$(-6$ 点)
[29点澫点]

II. 他賞所見 (6 点)

A. SLR (hamstring tightnesst含む)
a. 正常
b. $30^{\circ} \sim 70^{\circ}$
c. $30^{\circ}$ 未淽

B. 知覚
a. 正常
b. 軽度の知覚障害老有する
c、明白な知賞障害を認める
注 1 : 㪕度の知覚障害とは患者自身が認識しな い程度のもの
注 2 : 明白な知党障害とは知覚のいずれかの完 全脱出，あるいはこれに近いもので患者 自身も明らかに認識しているものをいう

C. 筋力
a. 非常
b. 軽度の筋力を低下
c . 明らかな筋力低下

注 1 : 被検筋を問わない

注 2 : 軽度の筋力低下上は筋力 4 程度を指す

注 3 : 明らかな筋力低下とは筋力 3 以下を指す 注 4 ：他覚所見が両側に認められる時はより障 害度の強い側で判定する

$\begin{array}{cc}\text { やや困難 } & \text { 容易 } \\ 1 & 2 \\ 1 & 2 \\ 1 & 2 \\ 1 & 2 \\ 1 & 2 \\ 1 & 2 \\ 1 & 2\end{array}$

$$
\begin{aligned}
& 0 \\
& -3 \\
& -6 \\
& \text { 改善率 }(\%)=\frac{\text { 治療後点数 }- \text { 治療前点数 }}{\text { 正常 }(29)-\text { 治療前点数 }} \times 100
\end{aligned}
$$

\section{表 2 Hendersonの評価法}

傮：疼痛はなく、入院前の職業に復㷌し、コル セットを必要としない。

良：時折疼痛があるが、入院前の職業に復帰し， コルセットは一日のうち30\%以上は必要とし ない。また，スポーツにも制限はない。

可：入院前より疼痛はよくなってるが，日常生活 動作に影響がある。コルセットを常用し、ス ポーツにも制限がある。

不可：入院前之疼痛は変わらす仕事も不可能であり， 治虔を絸けている。

Henderson ED, et al : JBJS 48-A, 1996
例につき単純 X線像上の椎間板高比（椎体横径に 対する椎間板高の比一片岡法), MRI上の椎間板 变性度 (Schneidermanの分類) ${ }^{(')}$, 軟骨終板 の信号変化を検討した。

術後経過観察期間は平均20か月（6-67か月） であった。

\section{結 果}

術前のJOAスコアは，11-25（平均18）点 経過観察時14-29（平均24）点であった. 平均改 
善率でみると退院時 $22 \% ， 3$ か月 $55 \%$ ，最終 $56 \%$ $(0-100 \%)$ であった。術後一時改善はみられ たが手術に移行した例が 6 例あった. Henderson の評価では，優23例，良11例，可10例，不可12例 （手術移行例 6 例を含む）であった，優，良あわ せた治療有効例は34例，61\%であった。

合併症として術中プローベの破損が 1 例, 術後
疼痛悪化が 2 例あったが, 神経症状の悪化例はな かった１例では術前の椎間板造影で隣接椎間に 椎間板炎が発生し，成績も不良であった。

画像所見上の椎間板高比は,術前平均0.46(0.35 $-0.58)$ が術後調查時平均 $0.45(0.34-0.58)$ で

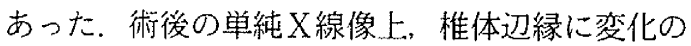
みられた例はなかったが，MRI上は 2 例で信号

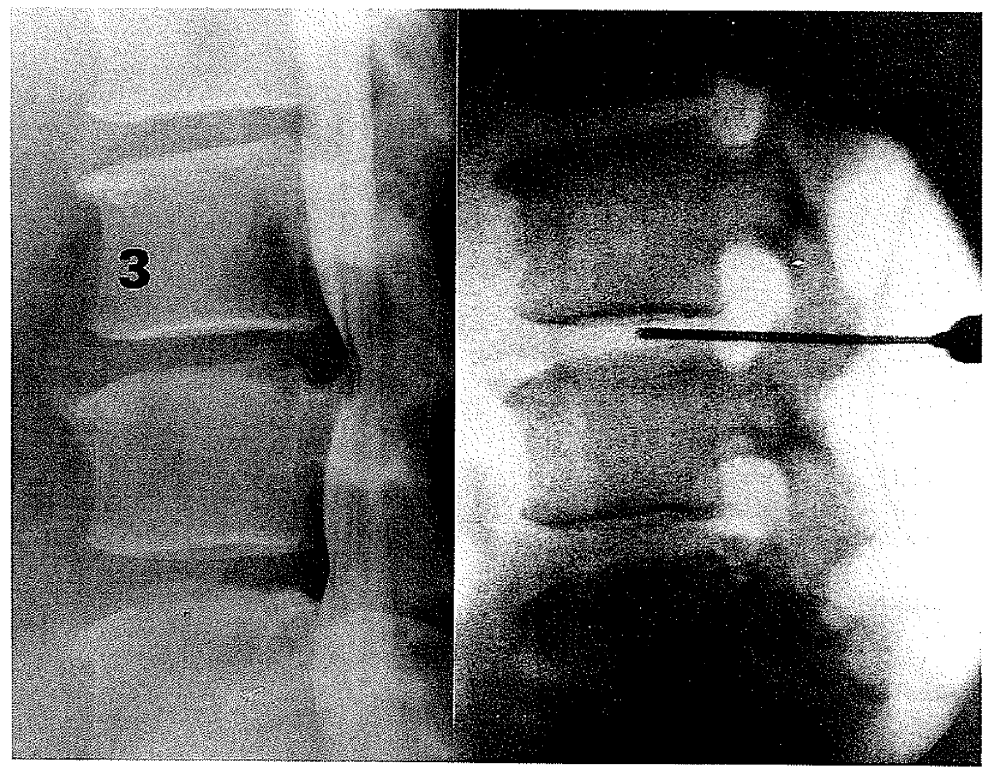

(a)

(b)

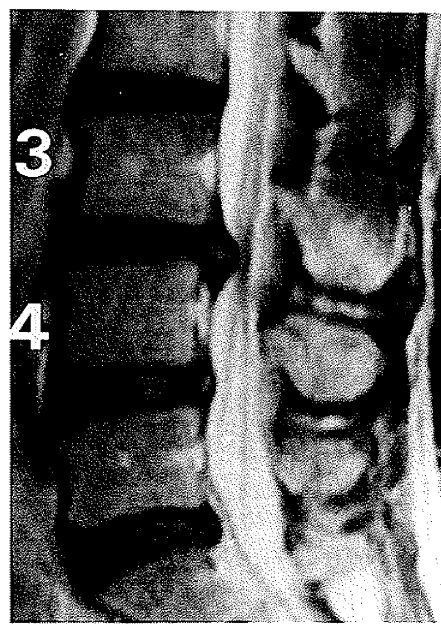

(c)

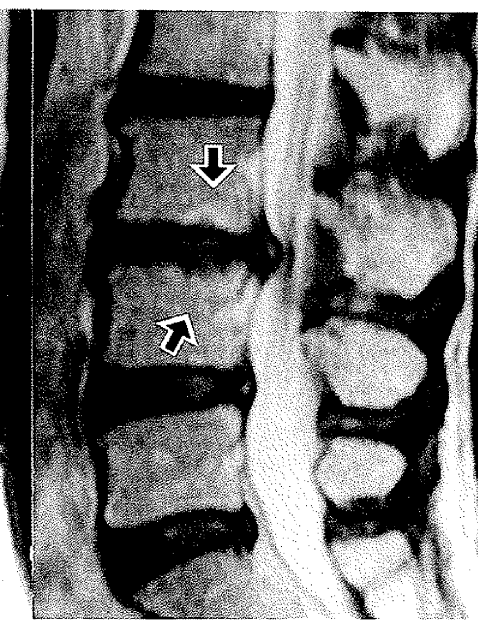

(d)

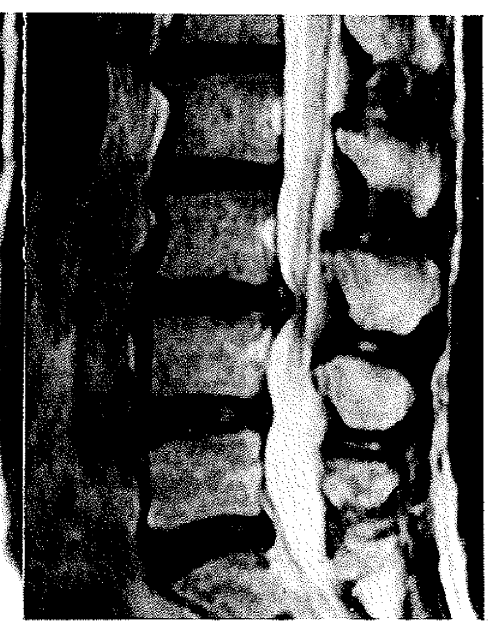

(e)

図 5 レーザーによる軟骨終板变化例（52歳，男性）

4 ヶ月来の左下肢痛で来院する. L 3 / 4 のsubligamentous extrusion型のヘルニアの診断で(a)，2190 Jのレーザーを照射する，レーザ一針は，椎間板のはぼ正中に刺入されている(b). MRI-T 2 像では，術 前(c)に比し，術後 7 週で椎体上下縁の信号变化が胃られる(d，矢印)。しかし，7ヶ月後にはその変化 はほぼ消失している(e).MRI上へルニアの縮小はみら机ないが, 術後 2 年の現在, 改善率は77\%, Hendersonの評俩は優である。 


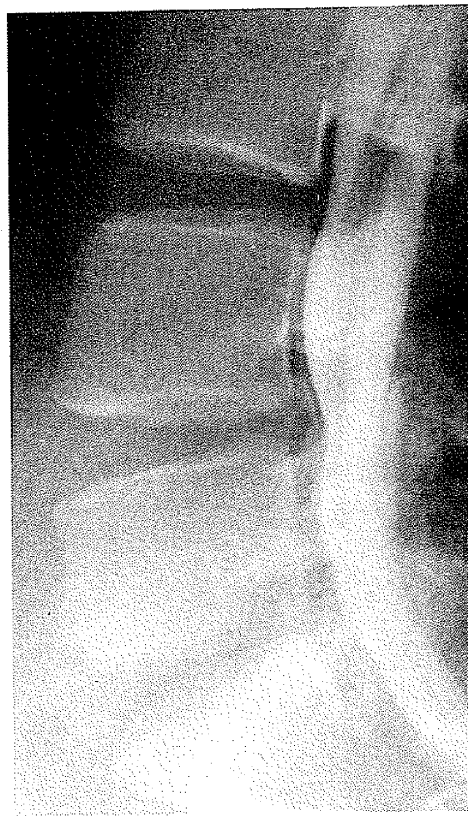

(a)

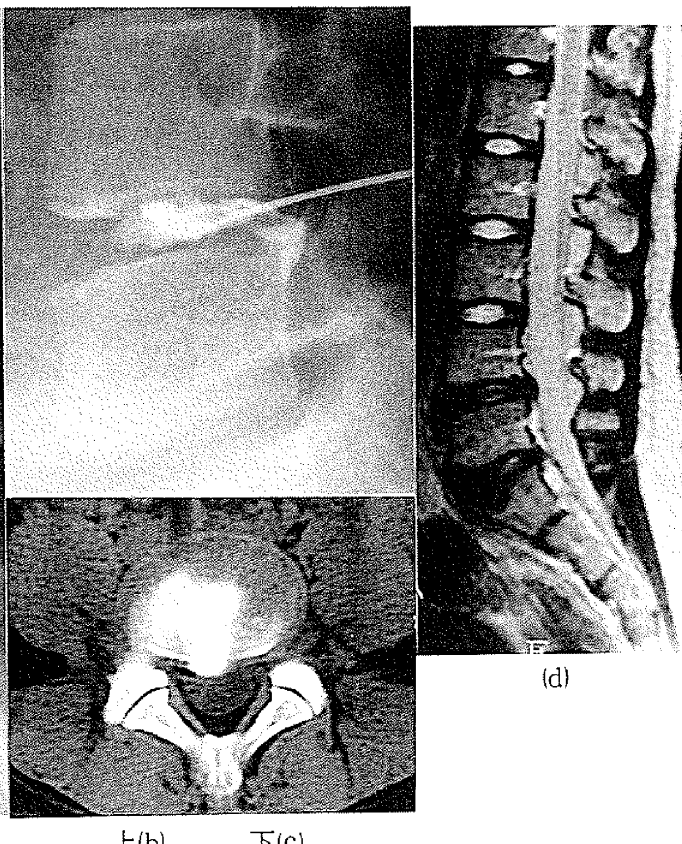

上(b) , 下(c)

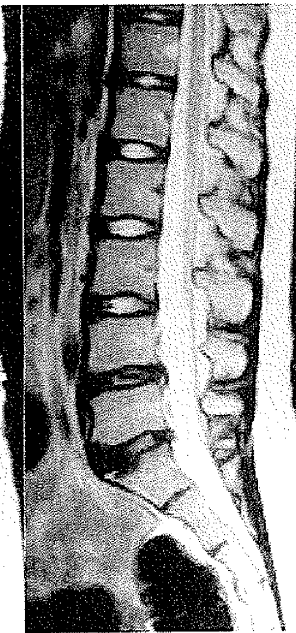

(e)

図 6 レーザ一有効例（症例 1）の画像所見

脊蹃造影像(a)，椎間板造影像(b)，CTD(c)でL 4/5間の右〜正中のヘルニアを示す. 術前MRI/d)に比し， 術後も髅核の信号变化は晃ら扎ず，ヘルニア像はやや縮小している(e).

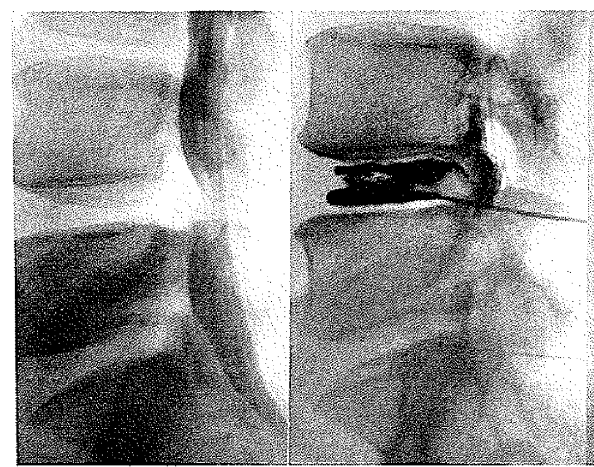

(a) (b)

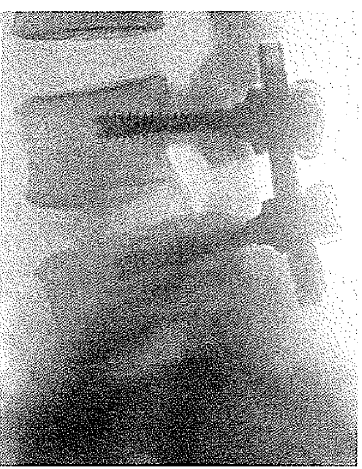

(c)

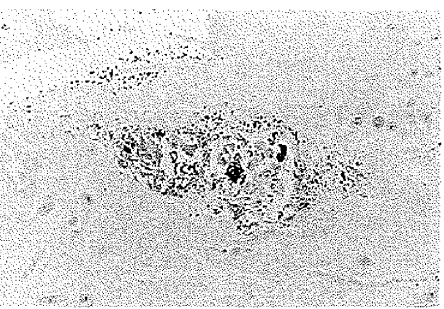

(d)

図 7 レーザー無効例（症例 2）の画像所見亡病理組織所見

a 脊髄造影像, b 椎間板造影像, c 椎間固定術後X線像. d 病理組織学的所見 $(\mathrm{HE}$ 染色 $\times 66)$

変化がみられた（図 5 )。椎間板の信号低下を認 めたのは12例であった．術後の画像上の变化之治 療成績との関連はみられなかった。

手術成績に影響を与える因子として，TLEの 4 例中 3 例亡下肢症状のない 5 例中 2 例の成績は 上くなかった，手術移行例はtension signが強く， 画像上ヘルニアが大きかった。16歳例は, 術前 protrusionの診断であったが，再手術所見では TLEで適応に問題があった，病理学的には, 線
維軟骨の粘液变性と部分的な壊死像がみられたが, 軟骨終板の破壊像はなかった。

\section{代表症例}

[症冽 1] 13歳, 女性, 中学 1 年生

2 年来の腰痛があり, 約10ヶ月前から疼痛が增 悪し，1時間の座っての就学が困難となった．近 医での治療が無効であったため, 紹介され当院を 受診した。入院時，下肢症状や神経学的異常なく， 
JOAスコアは20点であった，画像上は，L 4 / 5 間正中のSLE型ヘルニアで (図 $6 a-d$ ), $1995 \mathrm{~J}$ のレーザー照射を行った，照射直後ならび に1ヶ月㣪には症状に变化はなかったが，5ヶ月 後の来院時には症状は改善していた。術後 4 年の 現在, 患者は高校 3 年生となり，体育も普通にで き,JOAスコアは28点, 改善率は75\%となって いる，術後MRIでは，䯣核の信号にほとんよ゙变 化を認めない（図 6 e ）.

[症例 2] 28歳, 男性, 会社員

2 年来の腰痛と右に強い両下腿外側の疼痛で来 院した，SLRTは右 $60^{\circ}$ ，左 $30^{\circ}$ 陽性で，知覚障 害はL 5，S１領域にみられ，JOAスコアは13 点であった，画像上はL $4 / 5$ 間の大きなSLE 型ヘルニアであったため（図 $7 \mathrm{a} ， \mathrm{~b}$ ) 手術を勧 めたが，患者の希望が強く1867 Jのレーザーを照

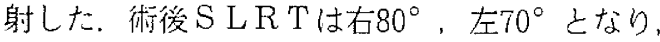
JOAスコアも15点と改善したため退院した。

しかし, 復職は困難で 2 ヶ月後の再入院した. 腰痛が強く, ヘルニアが正中であったため, 後方 侵入椎体間固定術を行いインスツルメントで固定 した（図７ｃ）。再手術後，JOAスコアは28点之 なり，復職した。手術時に採取した椎間板の病理 組織所見では，線維軟骨内に粘液变性した部位が みられ，その中の変性した軟骨細胞周囲には炭化 物がみられた（図７d）

\section{考 察}

レーザーを用いたPLDDは，最近我が国でも 行われるようになってきたが，保険適応がないこ ととレーザーの軟骨や骨に悪影響の問題があ る*・・．今回の検討では最終のJOAスコアを用 いた平均改善率は約 56\%, Hendersonの基準の 優，良をあわせた有効率は61\%であったが，基本的 にレーザー治療を希望して来院した例がほとんど であったため手術に移行した例も含め患者の満足 度は高かった，経過として術後 3 か月で改善傾向 にある例は、長期的に改善していた。 Protrusion, SLE例がPLDDの適応であるが，SLEでもへル ニアの大きい例, TLE例での成績は悪かった。
術後の画像所見で，椎間板の狭小化はみられず, MRI上の信号変化も軽度で, 我々の照射量は安 全生が高いことが確認された，そのことは除圧効 果が不十分なことを示しているので, さらなる至 適照射条件の検討が必要である。

\section{結 論}

Nd-YAGレーザーを用けたPLDDは60\%の症 例に有効であり，局所麻酔下で施行できる利点は 大きく，椎間板ヘルニアの 1 治療法として位置づ けられる，我々の使用している照射量では，骨や 軟骨への悪影響はみられなかったが，手技的には 椎間板の正中に針を刺入する事が肝要である.

本研究は日本学術振興会科学研究費補助金 (平 成11年〜13年度)により行われた。

\section{文 献}

1 ) Choy DSJ, Ascher PW, Saddekni S, et al: Percutaneous laser disc decompression. A new therapeutic modality. Spine 17 : 949-956, 1992.

2) Ohnmeiss DD, Guyer RD, Hochschuler SH, et al : Laser disc decompression. The importance of proper patients selection. Spine 19:2054-2059, 1994.

3) Yonezawa T, Onomura T. Kosaka R, et al : The system and procedures of percutaneous intradiscal laser nucleotomy. Spine $15: 1175-1185$. 1990.

4) 米澤卓奏, 小野村敏信：レーザーによる経皮的椎間 板骾核の蒸散法. MB Orthop '93增刊：117-119, 1993.

5 ）里見和彦，宮坂芳郎，小林 悟变か：腰椎椎間板へ ルニアに対するレーザ一喵核蒸散法の小経験。東日本 臨整会誌 $7 ： 73-78,1995$.

6) 小川川 潤，里見和彦、斯波卓哉ほか：レーザーによ る椎間板ヘルニア手術。整形外科50：918-924, 1999.

7 ) 斯波卓哉. 里見和彦、河合 大: 腰椎椎間板ヘルニ アに対するレーザー椎間板除压術. JMIOS N0.15：3338, 2000.

8) 鈴木省三, 宮内 晃, 岩崎幹季ほか：経皮的レー ザー椎間板除纴術（PLDD）のあと再手術を要した 症例の検討。臨整外 $35: 537-543 ， 2000$.

9) Nancy EE : Nerve root complications of percutaneous laser-assisted diskectomy performed at outside institutions: A technical note. J Spinal 
Disorders 7 : 510-512, 1994.

10）西島雄一郎, 石塚弘和, 愛川肇ほか：鏡視下経皮 的レーザー椎間板切除術。 日佱会誌 $6: 83-90,1995$.

11）里晃和彦：腰部椎間板造影の手技と実際. 整形・災 害外科 $24: 449-454 ， 1981$.

12）小坂理也, 米澤卓実, 田中真一郎ほか：レーザ一光 による椎間板ヘルニア治療一針先型圧センサーの開発 と評価. 日レ医誌10：281-283，1989.

13）椎間板ヘルニア，脊椎外科用語辞典（日本瓷椎外科 学会編），南江堂, 東京, pp. 49-51，1995.

14）井上俊一, 他：腰痛治療成績判定基準. 日整会誌 $60: 391-394,1986$

15) Henderson ED : Results of surgical treatment of spondylolisthesis. J Bone Joint Surg 48-A : 619-642, 1966.

16) Schneiderman G, Flannigan B, Kingston $S$, et al : magnetic resonance imaging in the diagnosis of disc degeneration: Correlation with discography. Spine $12: 276-281,1987$. 